\title{
Efektívnost' športovej prípravy mladších žiakov vo futbale
}

\section{The effectiveness of sports training younger pupils in football}

\author{
Luboš Benkovský, Martin Mikulič, Pavol Gregora, Pavol Peráček
}

\begin{abstract}
Fakulta telesnej výchovy a športu v Bratislave
\section{Abstrakt:}

Cielom projektu bolo prehíbit’ a rozšírit poznatky o športovom tréningu v základnej etape športovej prípravy mladšich žiakov vo futbale. Projekt prebiehal paralelne na dvoch mládežníckych výberoch hráčov tímu FC Spartak Trnava U12, (n:19, vek: 12,46 0,23, výška: 150,9 $\pm 6,92$ cm, hmotnost: $38,5 \pm 4,8 \mathrm{~kg}, \mathrm{KPF}: 63,85 \pm 7,79)$ a ŠK Senec U12, (n:17, vek: 12,34 $\pm 0,41$, výška: 146,3 $\pm 7,71 \mathrm{~cm}, \mathrm{hmot}-$ nost: $37,5 \pm 9,4 \mathrm{~kg}, \mathrm{KPF}: 70,95 \pm 5,37)$. Uplatňovali sme rozdielne prístupy z hladiska zložitosti obsahu tréningového procesu (metodické formy) medzi jednotlivými skupinami, ktorých pôsobenie sme pozorovali na zmene stavov vybraných ukazovatelov (Testy motorickej výkonnosti: rýchlost' $10 \mathrm{~m}, 30 \mathrm{~m}, 50$ $m, 5 \times 10 m$, lah-sed, skok do dial'ky z miesta, Légerov test, vertikálny výskok bez protipohybu) v časových fázach Dt0, Dt1, Dt2. Pri intraskupinovej komparácií testov podla časových fáz sme zistili pri FC Spartak Trnava U12 štatisticky významné rozdiely vo výsledkoch v takmer všetkých testoch v čase Dt0 a Dt2 na 1\% hladine štatistickej významnosti. V tíme ŠK Senec U12 boli zistené štatistické významné rozdiely na $1 \%$ hladine štatistickej významnosti v čase Dt0 a Dt2 vo výsledkoch v testoch rýchlosti $10 \mathrm{~m}, 30 \mathrm{~m}$, $50 \mathrm{~m}$, skok do dialky z miesta a v Légerovom teste. Pri analýze herné výkonu družstva boli zistené väčšie rozdiely v koeficientoch aktivity(Ka) a úspešnosti(Kú) obrannej a útočnej fázy hry v FC Spartak Trnava U12. Experimentálny obsah tréningového procesu efektívnejšie vplýval na skupinu, kde boli zvolené tréningové prístupy založené na vyššej zložitosti.
\end{abstract}

\begin{abstract}
:
The project aimed to deepen and broaden knowledge about sport training in basic phases of sports training younger pupils in football. The project runs parallel to the two youth player selection team FC Spartak Trnava U12, Slovakia (n: 19, age: $12.46 \pm 0.23$, height: $150.9 \pm 6.92 \mathrm{~cm}$, weight: $38.5 \pm 4.8 \mathrm{~kg}$; RHR $63.85 \pm 7.79$ ) and ŠK Senec U12, Slovakia (n: 17, age: $12.34 \pm 0.41$, height: $146.3 \pm 7.71 \mathrm{~cm}$, weight: $37.5 \pm 9.4 \mathrm{~kg}, R H R: 70.95 \pm 5.37)$. Applied have different approaches in terms of the complexity of the content of the training process (methodological forms) between groups, the activity we observed a change in the selected indicators (indicative of motor performance: speed of $10 \mathrm{~m}, 30 \mathrm{~m}, 50 \mathrm{~m}$, $5 \times 10 \mathrm{~m}$, lie-seat, long jump, Leger test, vertical jump without countermovement) in phases over time DTO, DT1, DT2. When intragroup comparison of test phases by the time we found out at FC Spartak Trnava U12 statistically significant differences in almost all the tests at the time DTO to DT2 and 1\% level of significance. The team ŠK Senec U12 were found statistically significant differences at the $1 \%$ level of significance at the time DTO and DT2 speed test in $10 \mathrm{~m}, 30 \mathrm{~m}, 50 \mathrm{~m}$, long jump and Leger test). When analyzing game performance were found major differences in the activity coefficient (Ka) and success (KU) offensive and defensive phases of play in FC Spartak Trnava U12. Experimental content of the training process more effectively influenced the group, which were selected training approaches based on greater complexity.
\end{abstract}

\section{Klíčová slova:}

Športová príprava, mladši žiaci, futbal, prípravné hry, zložitost'

\section{Key words:}

Sport training, younger pupils, football, small-sided games, complexity

Vedecký článok je súčastou grantovej úlohy UK/349/2015 


\section{ÚVOD}

Športová príprava mladých hráčov vo futbale ako jeden z druhov telovýchovného procesu, je progresívna forma prípravy mládeže, ktorou sa zvyšujú funkčné vlastnosti, rozvíjajú pohybové schopnosti a stimuluje zvyšovanie trénovanosti. Orientuje sa na nepretržité zvyšovanie výkonnosti, zabezpečuje zdravý životný štýl a optimálny harmonický vývin osobnosti futbalistov vplyvom pôsobenia prostriedkov telesnej výchovy a športu, ale i d’alších faktorov a podmienok (Kačáni, 1980; Israel, Eissmann, 2007).

Športovú prípravu mladých hráčov vnímame ako samostatný proces s vlastnými ciel’mi, ktoré nie sú podriadené hlavnému ciel'u. Odráža sa to v programoch tréningového procesu, kde sa vyskytuje znatel'ný podiel špeciálne zameraného tréningu (Peráček, 2003).

Pod strategickým ciel'om športovej prípravy mladých futbalistov nemôžeme chápat' okamžitú maximalizáciu výsledkov už v najmladších vekových kategóriách, ale vytvorenie funkčného základu pre ich dosiahnutie v kategórií dospelých (Peráček, 1993). Výsledky rôznych analýz poukazujú, že tréneri mnohokrát nedodržujú vzor perspektívneho tréningu a počítajú s maximalizáciou výsledkov už v najmladších kategóriách. A to je jedna z príčin predčasného ustálenia výkonu viacerých hráčov, ktorí v danej vekovej kategórií spĺn̆ajú najvyššie prognostické kritéria. Príliš zriedka sa pozastavujeme nad účinkami tréningu v jednotlivých etapách športovej prípravy (Peráček, 2003, 2004).

„Deti nie sú malí dospelí!“

Tréning mladých hráčov vo futbale nemôže byt' redukovaný, kopírovaný prípadne miniaturizovaný tréning v objeme a intenzite dospelých. Musí byt' úmerný ich momentálnemu stupňu vývoja, inak môže viest' $\mathrm{k}$ negatívnym reakciám mladého organizmu $\mathrm{v}$ oblasti psychickej, ale hlavne anatomicko-fyziologickej (Bisanz, 1983, 1986; Vengloš, 1988; Votík 2005).

Deti a mládež majú iné fyzické a psychické predpoklady pre tréningovú a zápasovú činnost' a zároveň s narastajúcim vekom dochádza $\mathrm{k}$ podstatným zmenám. Často sa na rešpektovanie vekových zvláštností mládeže zabúda, či už ide o určovanie tréningového obsahu, vel'kost' dávkovania, tréningové metódy a formy, ako aj na určovanie požiadaviek na herný výkon v zápasoch, preto musíme dôrazne prihliadat' na prispôsobenie metód a prostriedkov vekovým zvláštnostiam (Bisanz, 1989; Fini, 1989; Buzek, Procházka, 1999).

Jedine dlhodobou, ciel'avedomou, racionálnou a systematickou športovou prípravou mladých futbalistov s jednotným, účelným a vedecky zdôvodneným systémom ciel'ov, postupov a podmienok dosiahneme vysokú úroveň športovej výkonnosti v seniorskom veku (Peráček, 1992; Weineck, 2000; Kačáni, 2000; Perič, 2004).

Kačáni s Horským (1988) tvrdia, že bez modernizácie nie je možné zvyšovat' efektívnost' tréningového procesu. Ide hlavne o modernizáciu jeho obsahu, metód, ciel'ov, súčastí, foriem atd'. $\mathrm{s}$ akcentom na možnosti využívania, $\mathrm{v}$ súčasnosti realizovanej, spolupráce členov realizačných tímov na rozličných úsekoch trénerskej práce. Tréningový proces a jeho požiadavky na modernizáciu sú zhodné s požiadavkami nahradit' zastarané niečím progresívnym, novým. To zodpovedá momentálnej situácií rozvoja športovej vedy, techniky, mysleniu vzdelaných trénerov a taktiež vedeckej teórií športového tréningu vo futbale (Lochmann, 2001; Carling, 2001; Ward, et al., 2002; Peráček, 2002; Žamba, Holienka, 2012).

Medzi najznámejšie vývojové tendencie vo futbale patrí intenzifikácia hry. Intenzifikáciou nerozumieme pripravenost' hráča len z nešpecifickej stránky, ale pod intenzifikáciou chápeme aj zvýšenie počtu hernej situačnosti $v$ zápasoch, z čoho vyplýva neustály rozvoj zručnostného potenciálu - umenia hrat' a ovládat' loptu, čo je v príprave mládeže vel'mi podstatné. Učíme hráčov hrat' futbal „,eez futbal“, čiže v tréningovom procese využívame zložitejšie metodické formy najviac podobajúce sa podmienkam zápasu. Hráči musia byt' schopní riešit' herné situácie počas celého zápasu aj v stave únavy a pod časovo-priestorovým tlakom. Preto je tendencia využívat'v tréningovom procese podnety, ktoré sú svojim charakterom podobné hrám, tzv. všetko s loptou.

Fyziologické, sociálne, psychologické, technické a taktické faktory ovplyvňujú výkon futbalistov (Bangsbo, 1994). Pri plánovaní tréningového procesu berieme do úvahy všetky faktory a na futba- 
listov pôsobíme komplexne (Jones, 2007), tréningové podnety sú podobné zápasovým podmienkam (Mallo, 2008). Aby bolo možné integrovat' realitu hry s tréningom, tréneri sa snažia napodobnit' fyzické, technické a taktické požiadavky, prispôsobit úlohu špecifickosti hry, zmenšujú jej formy a asimilujú s ciel'om tréningu (MacLaren, 1988; Hoff, et al., 2002; Reilly, 2004; Mallo, 2008). Touto cestou sa taktické a technické faktory efektívne prenášajú do podmienok futbalového zápasu (Williams, 2003). Rôzne úpravy, ktorými zmenšujeme hru na malé časti, sú označené, ako malé formy prípravných hier alebo prípravné hry s malým počtom hráčov. Malé formy prípravných hier (MFPH) tréneri zvyčajne využívajú s ciel'om rozvíjat' technické zručnosti alebo kondičnú zdatnost' futbalistov, ktorá v etape základnej športovej prípravy nehrá významnú rolu (Rampinini, 2007; HillHaas, 2008; Hill-Haas et al., 2009).

V etape základnej športovej prípravy sa nezameriava na rozvoj bioenergetických systémov, ale hlavnou úlohou v našom experimente pri presadzovaní zložitejších foriem herného tréningu a prípravných hier bude komplexnejšie rozvíjat' hernú spôsobilost' hráčov.

\section{METODIKA}

Výskum prebiehal paralelne na dvoch mládežníckych výberoch hráčov tímu FC Spartak Trnava U12, (n:19, vek: 12,46 \pm 0,23, výška: 150,9 $\pm 6,92 \mathrm{~cm}$, hmotnost': 38,5 $\pm 4,8 \mathrm{~kg}, \mathrm{KPF}: 63,85 \pm 7,79$ ) a ŠKK Senec U12, (n:17, vek:12,34 \pm 0,41, výška:146,3 \pm 7,71 cm, hmotnost': $37,5 \pm 9,4 \mathrm{~kg}$, KPF:70,95 $\pm 5,37$ ), ktorý sú účastníkmi 1 . futbalovej ligy mladších žiakov na Slovensku.

Realizácia výskumu prebiehala $\mathrm{v}$ podmienkach dvojskupinového jednofaktorového paralelného experimentu $v$ prirodzených podmienkach tréningového procesu. Jeho pomocou sme overovali vplyv navrhnutého modelu prípravy mladých futbalistov v etape základnej športovej prípravy.

Priebeh experimentu predstavoval pôsobenie na experimentálnu skupinu (FC Spartak Trnava U12) experimentálnym podnetom (EP) a na kontrolnú skupinu (ŠK Senec U12) kontrolným podnetom (KP), ktorých vplyv sme sledovali na zmenách stavov analyzovaných ukazovatel'ov motorických testov a herného výkonu družstva v útočnej a obrannej fáze hry $(\mathrm{St} 1, \ldots \mathrm{St} 8) \mathrm{v}$ časových intervaloch Dt0, Dt1, Dt2.

Experimentálny činitel' experimentálnej skupiny bude predstavovat':

1. Proporcionalita súčastí tréningového procesu s dominanciou herného tréningu.

2. Väčšie zastúpenie špecifických herných činností oproti nešpecifickým kondičným činnostiam.

3. Zameranie tréningových procesu na dominantné postavenie malých foriem prípravných hier $\mathrm{v}$ hernom tréningu

Tabulka 1: Proporcionalita súčastí tréningového procesu v experimentálnom a kontrolnom súbore

\begin{tabular}{|l|c|c|c|}
\hline Skúmané súbory & Kondičný tréning & Herný tréning & Herný nácvik \\
\hline Experimentálna skupina (ES) & $20 \%$ & $60 \%$ & $20 \%$ \\
\hline Kontrolná skupina (KS) & $20 \%$ & $20 \%$ & $60 \%$ \\
\hline
\end{tabular}

Stanovili sme si dva základné rozdiely medzi experimentálnou skupinou a kontrolnou skupinou $\mathrm{v}$ hernom tréningu a hernom nácviku. V experimentálnej skupine bude najväčší podiel v hernom tréningu (60\%), zatial' čo v kontrolnej skupine tvorí herný tréning iba $20 \%$. Najväčšie zastúpenie v kontrolnej skupine má herný nácvik $(60 \%)$.

Tabulka 2: Proporcionalita metodických foriem v experimentálnej a kontrolnej skupine v rámci herného tréningu

\begin{tabular}{|l|c|c|c|}
\hline Experimentálne skupiny & Prípravné cvičenia & Herné cvičenia & Prípravná a vlastná hra \\
\hline Experimentálna skupina (ES) & $30 \%$ & $10 \%$ & $60 \%$ \\
\hline Kontrolná skupina (KS) & $30 \%$ & $30 \%$ & $40 \%$ \\
\hline
\end{tabular}


V Experimentálnej skupine sme sa z pohl'adu metodických foriem $\mathrm{v}$ hernom tréningu rozhodli prevažnej miere využívat' prípravne hry $(60 \%)$ a v kontrolnej skupine bola proporcionalita pomerne rovnako zastúpená. $\mathrm{V}$ prípravných hrách predstavovali tieto rozdiely $20 \%$ a $\mathrm{v}$ herných cvičeniach $20 \%$ medzi jednotlivými skúmanými skupinami. V experimentálnej skupine budeme preferovat' malé formy prípravných hier $(60 \%)$.

Hráčov sme podrobili trom meraniam (St1 - St8) s časovým odstupom (Dt0, Dt1, Dt2) na nižšie uvedených motorických testoch, ktoré boli vykonané na futbalových ihriskách s umelým povrchom.

\section{Motorické testy:}

\section{St1. - Beh na 10 metrov}

Účel: Test meria rýchlost’ reakcie, maximálnej schopnosti akcelerácie na krátkej bežeckej trati.

St2,3. - 30, 50 metrov

Účel: Zist’ujeme rýchlost' akcelerácie a maximálnej bežeckej rýchlosti na danom úseku.

\section{St4. - Beh 5x10metrov}

Účel: Motorický test $5 \times 10$ metrov skúma úroveň rýchlostných schopností - akceleračnú rýchlost'. Ak chápeme agilitu ako zloženú pohybovú schopnost' (beh so zmenami smeru), tak pomocou tohto testu zist'ujeme aj úroveň agility.

\section{St5. - Výskok z drepu bez protipohybu}

Účel: Zist’ujeme úroveň výbušnej sily dolných končatín.

\section{St6. - Skok do dial'ky z miesta}

Účel: Test meria úroveň výbušnej sily svalov dolných končatín

\section{St7.- Légerov test / Yo-Yo test}

Účel: Týmto testom zist'ujeme úroveň vytrvalostných aeróbnych schopností.

St8.- Lah-sed

Účel: Dynamická a vytrvalostná sila brušného a bedrovo-stehenného svalstva.

Herný výkon družstva podl’a Peráčka (2012) bol analyzovaný v prvých a posledných troch majstrovských stretnutiach v kategórii U12 mladších žiakov. Herný výkon družstva v obrannej a útočnej fáze hry bude konečný ukazovatel' pôsobenia nastaveného tréningového programu pri porovnaní oboch tímov:

\section{Útočná fáza hry:}

- Výpočet koeficientov ÚF hry:

Koeficient aktivity $=\Sigma$ Útočných fáz (ÚF) $/ \Sigma$ Strel'by

$\mathrm{Ka}=\frac{\sum \dot{U} F}{\sum S}$

Koeficient aktivity útočnej fázy vyjadruje pomer všetkých útočných fáz hry k počtu útočných fáz hry zakončených strel'bou.

Koeficient úspešnosti $=\Sigma$ Útočných fáz (ÚF) $/ \Sigma$ Striel do priestoru brány

$\mathrm{Kú}=\frac{\sum \dot{U} F}{\sum S p b}$

Koeficient úspešnosti útočnej fázy vyjadruje pomer všetkých útočných fáz hry k počtu útočných fáz hry zakončených strel'bou do priestoru brány.

Koeficient efektivity $=\Sigma$ Striel do priestoru brány $/ \Sigma$ Gólov 
$\mathrm{Ke}=\frac{\sum S p b}{\sum G}$

Koeficient efektivity útočnej fázy udáva pomer počtu striel smerovaných do priestoru brány k počtu striel potrebných na dosiahnutie gólu.

Kvalitu jednotlivých ÚHS charakterizujú koeficienty. Čím je číslo daného koeficientu bližšie k číslu 1, tým je sledovaný parameter ÚHS kvalitnejší. Ak v parametroch, ktoré tvoria jednotlivé vzorce koeficientov, sa objaví číslica 0 (t.j. útočné fázy, počet striel, počet striel do priestoru brány, góly), tak to znamená, že daný ÚHS nebol vôbec realizovaný, úspešný, resp. efektívny.

\section{Obranná fáza hry:}

- Výpočet koeficientov OF hry:

Koeficient aktivity $=\Sigma$ Obranných fáz (OF) $/ \Sigma$ Strel'by (S)

$\mathrm{Ka}=\frac{\sum O F}{\sum S}$

Koeficient aktivity hráčov v obrannej fáze hry vyjadruje pomer všetkých obranných fáz hry k počtu obranných fáz hry, v ktorých umožníme súperovi zakončit' útočnú fázu strel'bou.

Koeficient úspešnosti $=\Sigma$ Obranných fáz (ÚF) $/ \Sigma$ Striel do priestoru brány (Spb)

$\mathrm{Kú}=\frac{\sum O F}{\sum S p b}$

Koeficient úspešnosti obrannej fázy hry vyjadruje číselnú hodnotu vyjadrenú pomerom všetkých obranných fáz hry k počtu obranných fáz hry, v ktorých hodnotené družstvo umožní súperovi zakončit' jeho útočnú fázu hry strel'bou do priestoru brány.

Koeficient efektivity $=\Sigma$ Striel do priestoru brány $(\mathrm{Spb}) / \Sigma$ Gólov $(\mathrm{G})$

$\mathrm{Ke}=\frac{\sum S p b}{\sum G}$

Koeficient efektivity obrannej fázy hry predstavuje číselnú hodnotu vyjadrený počtom obranných fáz hry sledovaného družstva k počtu striel, ktoré potrebovalo útočiace družstvo na dosiahnutie gólu. Č́m je hodnota jednotlivých koeficientov vyššia tým viac je kvalitnejšia obranná fáza sledovaného súboru.

\section{VÝSLEDKY}

Počas sledovaného obdobia sme zaznamenávali všetky tréningové ukazovatele, kde pre nás hlavný obsah tréningového procesu predstavovali špeciálne tréningové ukazovatele (ŠTU). Celkový objem špeciálnych tréningových ukazovatel'ov v tíme FC Spartak Trnava je 6911 minút a v tíme ŠK Senec 4980 minút za obdobie experimentu. Na základe proporcionality sú špeciálne tréningového ukazovatele rozložené v kondičnom tréningu (KT), hernom tréningu (HT) a hernom nácviku (HN). V FC Spartak Trnava U12 bolo dominantné postavenie herného tréningu s 5042 minútami, čo tvorilo $73 \%$ celkového objemu zat'aženia, nasleduje 1520 min (22\%) kondičného tréningu a 346 min (5\%) herného nácviku. V ŠK Senec sme sa zameriavali na herný nácvik s 2689 minútami (54 \%), hlavne vel'ké množstvo opakovaní herných činností jednotlivca, 1245 minút (25\%) herného tréningu a najmenší objem 1046 minút (21\%) kondičnému tréningu. Pri podrobnejšej proporcionalite herného tréningu sme zaevidovali v tíme FC Spartak Trnava nasledovné objemové rozloženie metodických foriem, prípravné hry 3532 minút (70\%), prípravné cvičenia 1261 (25\%) a herné cvičenia 252 
(5\%). ŠK Senec 573 minút (46\%) prípravných hier, 336 minút (27\%) herných cvičení a 336 minút (27\%) prípravných cvičení.

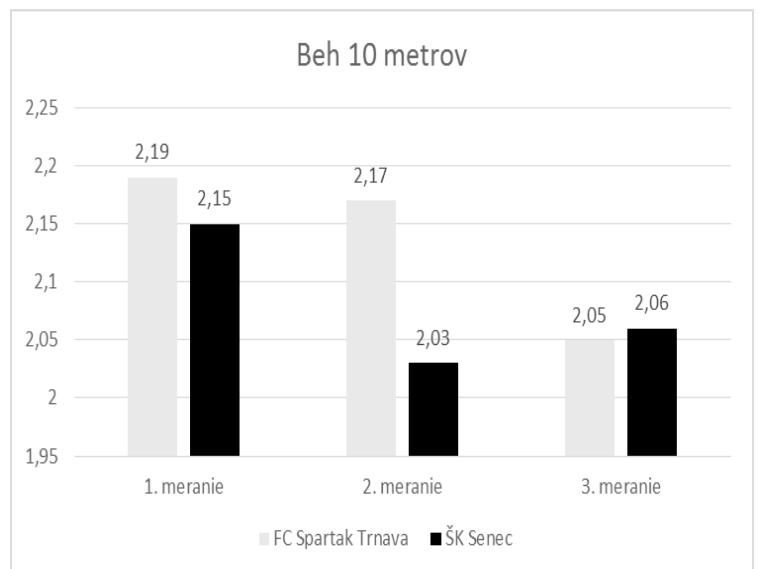

Obrázok 1: priemerný čas (s) v behu na $10 \mathrm{~m}$

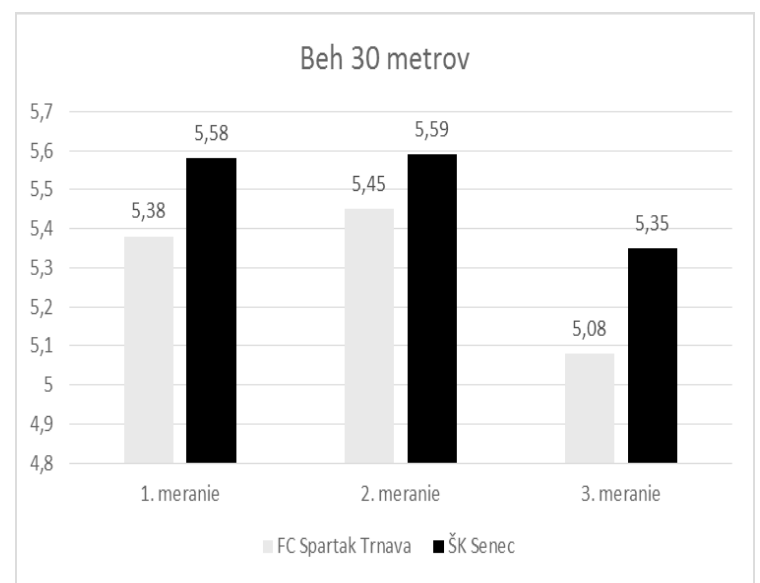

Obrázok 2: priemerný čas (s) v behu na $30 \mathrm{~m}$

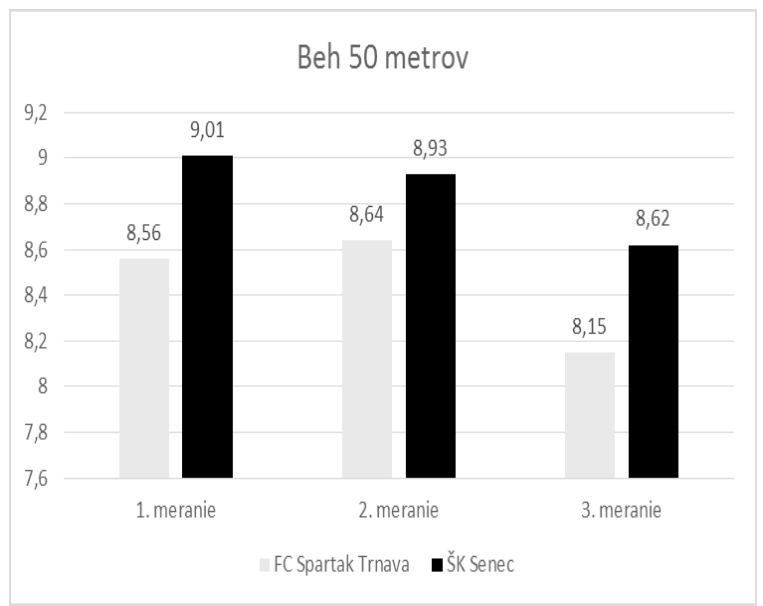

Obrázok 3: priemerný čas (s) v behu na $50 \mathrm{~m}$ 


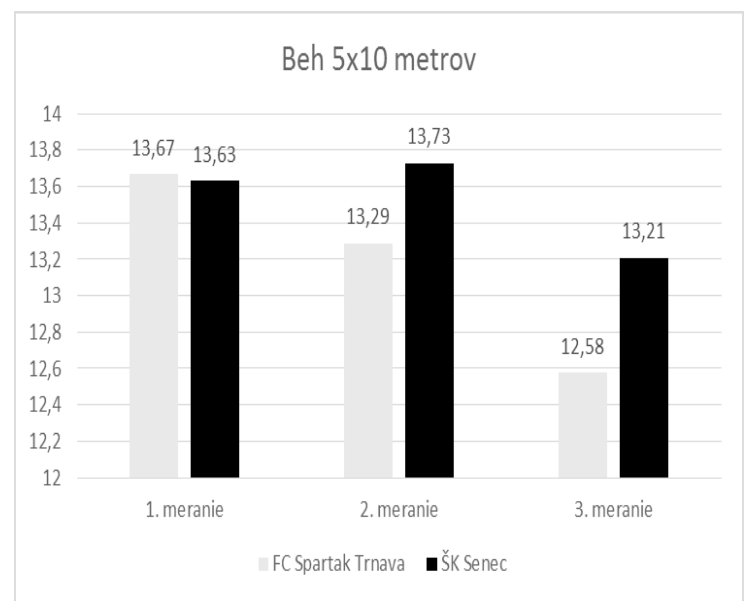

Obrázok 4: priemerný čas (s) v behu 5 × 10 m

V rýchlostných testoch sme zistili signifikatne významné zlepšenia medzi prvým a tretím meraním takmer vo všetkých testoch $\mathrm{v}$ oboch skupinách $(\mathrm{p} \leq 0,01)$. Jedine $\mathrm{v}$ teste beh $5 \times 10$ metrov sa nenašla štatistická významnost’ pri porovnaní prvého a tretieho merania hráčov ŠK Senec.

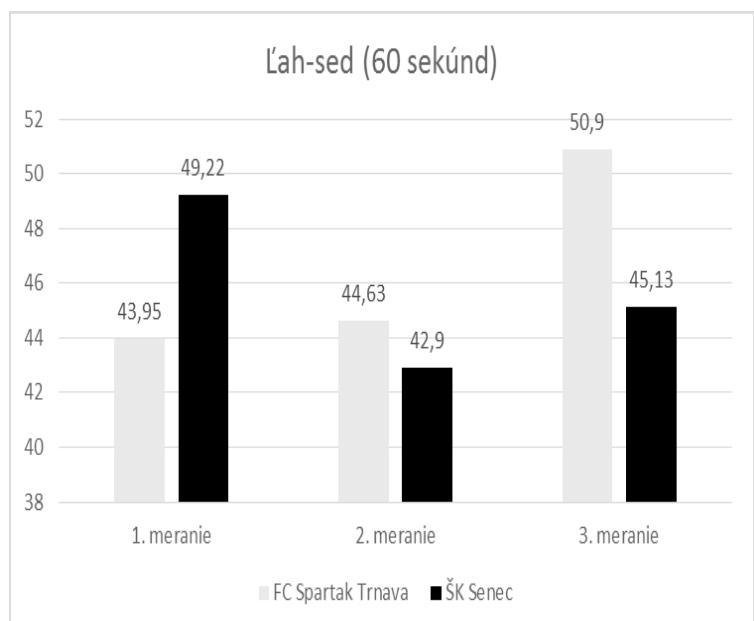

Obrázok 5: priemerný počet opakovaní v teste L’ah-sed za 60 sekúnd 


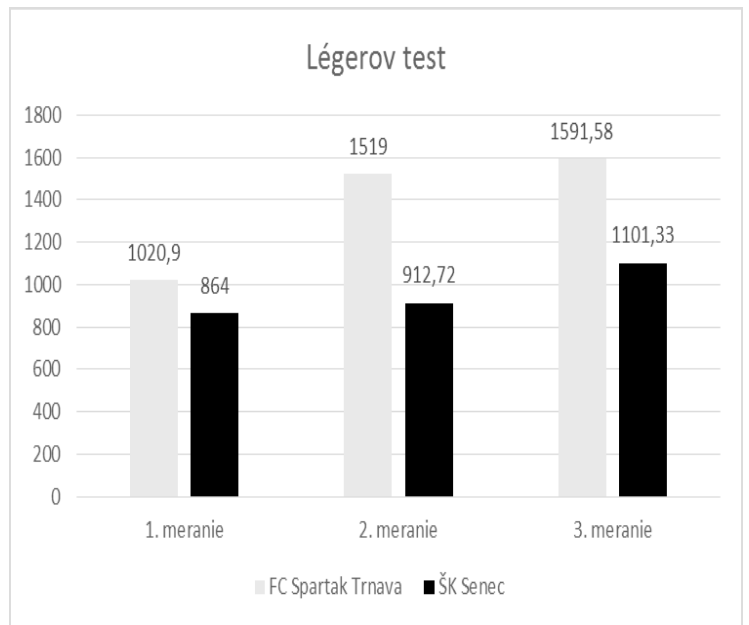

Obrázok 6: priemerný počet odbehnutých $(m)$ v Légerovom teste

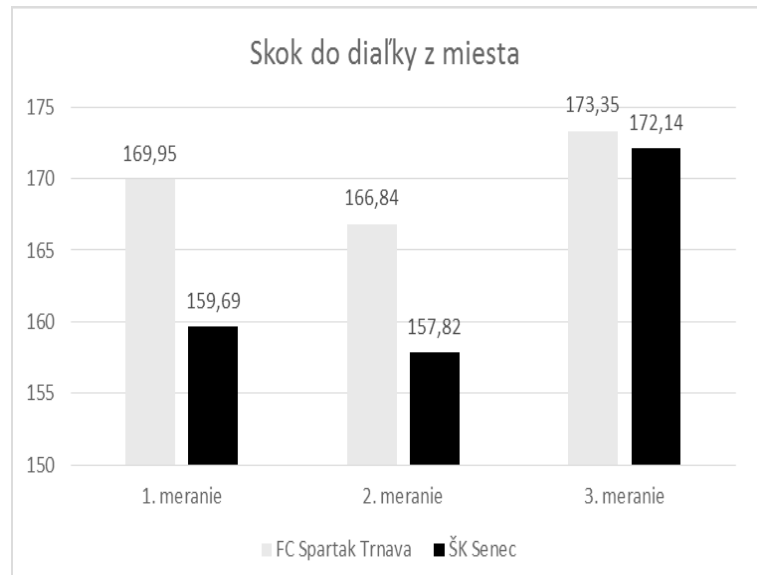

Obrázok 7: priemerná vzdialenost' $(\mathrm{cm})$ v teste skok do dial'ky z miesta

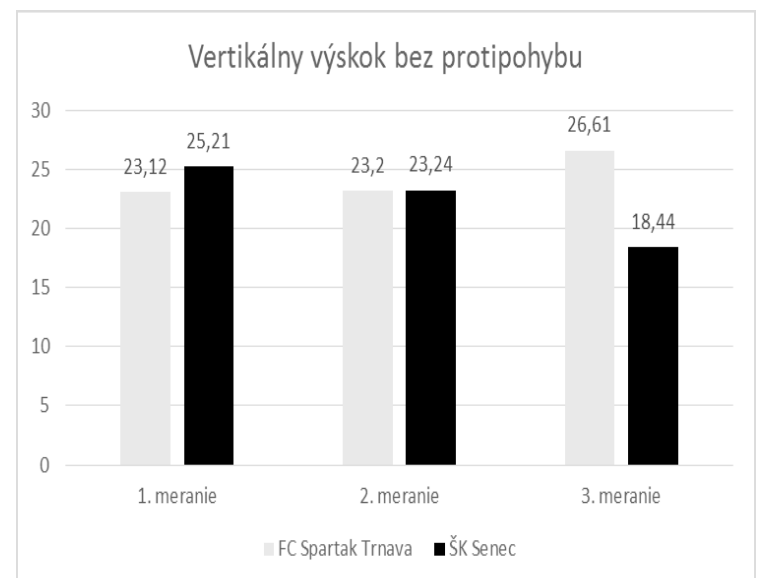

Obrázok 8: priemerný výskok (cm) v teste vertikálny výskok bez protipohybu 
V teste vertikálny výskok bez protipohybu $(\mathrm{p} \leq 0,01)$ sme našli signifikatné rozdiely, kde u hráčov ŠK Senec je badatel'ný regres výkonnosti v motorickom teste medzi prvým a tretím meraním. Štatistické významne zlepšenie $(\mathrm{p} \leq 0,01)$ sme následne zistili $v$ testoch vertikálny výskok bez protipohybu, l'ah-sed a asi najväčší rast výkonnosti sme zaznamenali v Légerovom teste pri tíme FC Spartak Trnava medzi prvým a tretím meraním, čo pripisujeme hlavne aplikovaniu malých foriem prípravných hier, ktoré tvorili dominantné postavenie v tréningovom procese. Signifikatné rozdiely boli zistené aj v ŠKK Senec, kde v teste skok do dial'ky z miesta a Légerovom teste bola zistená štatistická významnost' na $1 \%$ hladine.

Tabulka 3: Kvalita obrannej fázy hry experimentálnych skupín

\begin{tabular}{|l|l|l|l|l|l|l|l|l|}
\hline \multirow{3}{*}{ Skupina } & \multicolumn{6}{|c|}{ Kvalita obrannej fázy hry } \\
\cline { 2 - 8 } & Počet OF & \multicolumn{2}{|c|}{ Ka } & \multicolumn{2}{c|}{ Kú } & \multicolumn{2}{c|}{ Ke } \\
\cline { 2 - 8 } & 1. & 2. & 1. & 2. & 1. & 2. & 1. & 2. \\
\hline FC Spartak Trnava & 208 & 190 & 2,77 & 4,87 & 4,95 & 10,0 & 2,33 & 2,52 \\
\hline ŠK Senec & 193 & 218 & 2,57 & 2,36 & 4,02 & 2,31 & 2,00 & 2,47 \\
\hline
\end{tabular}

Kvalita obrannej fázy (OF) hry je tým lepšia, čím vyššie sú výsledné koeficienty aktivity (Ka), úspešnosti (Kú) a efektivity (Ke). Jednotlivé koeficienty sme získali pri konečnej kalkulácii výsledných hodnôt počtu obranných fáz, strel'by, strel'by do priestoru brány a strel'by, ktorá skončila gólom. Na základe podrobnej analýzy sme zistili tendencie poklesu obranných fáz FC Spartak Trnava a zároveň sa zvýšili koeficienty aktivity a úspešnosti. Rozdiel v koeficiente aktivity medzi analýzami je približne o 2 obranné fázy, kde družstvá súperov potrebovali o 2 útočne fázy. Počet sa zvýšil z približne 3 (Ka 2,77) na 5 (Ka 4,87) útočných fáz, ktoré súper potreboval na zakončenie útoku strel'bou. Tak isto sme zistili nárast koeficientu úspešnosti, kde stúpol z približne 5 (Kú 4,95) na 10 (Kú), čo znamená, že súper potreboval o 5 útočných fáz viac na zakončenie útoku strel'bou do priestoru brány. Pri družstve ŠK Senec sme spozorovali negatívny ukazovatel' pri koeficiente úspešnosti, kde súper potreboval o 2 útočné fázy menej na zakončenie útoku strel'bou do priestoru brány, ako to bolo na začiatku experimentu.

Tabulka 4: Kvalita útočnej fázy hry experimentálnych skupín

\begin{tabular}{|l|l|l|l|l|l|l|l|l|}
\hline \multirow{3}{*}{ Skupina } & \multicolumn{6}{|c|}{ Kvalita útočnej fázy hry } \\
\cline { 2 - 8 } & Počet ÚF & \multicolumn{2}{|c|}{ Ka } & \multicolumn{2}{c|}{ Kú } & \multicolumn{2}{c|}{ Ke } \\
\cline { 2 - 9 } & 1. & 2. & 1. & 2. & 1. & 2. & 1. & 2. \\
\hline FC Spartak Trnava & 242 & 280 & 3,70 & 1,80 & 5,56 & 2,45 & 2,36 & 3,67 \\
\hline ŠK Senec & 178 & 199 & 2,74 & 2,36 & 4,56 & 4,73 & 1,85 & 2,47 \\
\hline
\end{tabular}

Pri kvalitne útočnej fázy(ÚF) hry je dôležitý koeficient, čo najviac približujúci sa číslu 1. Koeficienty sme získali kalkuláciou výsledných hodnôt počtu fáz, strel'by, strel'by do priestoru brány a strel'ba, ktorá skončila gólom. V obidvoch tímoch je zistený nárast počtu útočných fáz. Tak ako v obrannej fáze hry je zretel'ný rozdiel v koeficiente aktivity a úspešnosti skupiny FC Spartak Trnava. Rozdiel prvého spomínaného koeficientu je z približne 4 (Ka 3,70) na 2 (Ka 1,80), kde sa družstvo dokázalo z každej druhej útočnej fázy dostat' do zakončenia. V druhom koeficiente je badatel'né zlepšenie z počtu približne 6 (Kú 5,56 ) na približne 2 (Kú 2,45), kde družstvo potrebovalo o približne 4 útočne fázy menej na zakončenie útoku strel'bou do priestoru brány. $V$ druhej skupine sme nespozorovali výrazný rozdiel medzi koeficientami kvality na začiatku a konci experimentu. 


\section{DISKUSIA}

Je pravdepodobné, že dôvodom zlepšenia v sledovaných ukazovatel'och herného výkonu je vplyv prípravných hier. Tieto metodické formy sme preferovali v experimentálnej skupine. Prípravné hry svojou organizáciou rozvíjajú súčasne nielen kondičné, technické, taktické, teoretické determinanty herného výkonu, ale aj kognitívne schopnosti. Neustála zmena herných situácií, ich alternatívnost', variabilnost' a časová tieseň nútia hráčov udržiavat' psychické procesy a kognitívne schopnosti na vysokej úrovni.

Významné postavenie herne orientovaného tréningu u mládeže zdôrazňuje Bruggemann, Albrecht (1982), ktorí chápu konanie hráča $\mathrm{v}$ jeho situačne podmienených spôsoboch prejavu, ako ucelený prvok učenia, v ktorom sa vyskytujú jednotlivé technické, taktické, psychické a fyzické faktory na rozličnom stupni ich rozvoja, ale vždy spoločne. V nej sa realizuje tréningový ciel', podl'a ktorého úspešný priebeh hry nemá primárny význam to, ako treba určitú činnost' vykonat', ale to, aby bola činnost' vykonaná adekvátne podl'a podmienok hernej situácie a zaručovala úspech a aby bola pre súpera nepredvídatel'ná. Taktiež Hedergott (1973) uprednostňuje ako hlavný ciel' v tréningu všetkých vekových kategóriách zlepšenie správania v sút’ažnom boji.

McMorris a kol. (1999) zistili, že intenzifikáciou ponímanou ako zvýšenie hernej situačnosti, t. j. malé formy prípravných hier v tréningovom procese, sa signifikatne zrýchl'uje rozhodovanie sa, preto vylučovaním adrenalínu a noradrenalínu sa zvyšuje úroveň podráždenia CNS. Práve tieto zistenia sú argumentom, že práve prípravné hry, ako tréningové prostriedky so zvýšenou hernou situačnost'ou boli determinantom znižovania času rozhodovania sa hráčov v herných situáciách. Vel'ký význam pri vykonávaní a regulácii pohybov v herných situáciách (Štulrajter, Peráček, 2004) zohráva extrapyramídový motorický systém (EPMS) a pyramídový systém mozgovej kôry (PS).

Pri motorickom učení každý pohybový prejav prebieha najprv cez neustálu vedomú kontrolu. Ustavičným opakovaním konkrétneho pohybu vzniká prepojenie aktivovaných neurónov do ret’azca, ktorý zosobňuje daný pohyb. Vzniká určitá šablóna pohybu na neurónovej úrovni - motorický inervačný vzor, pri ktorom spolupracuje kôrové centrum pyramídového systému s EPMS. Po zvládnutí konkrétneho pohybu sa do EPMS (do podkôrových oblastí) uložia tieto motorické inervačné vzory. Znamená to, že hráč vykonáva pohyb bez toho, aby nad ním musel premýšlat'. Neustálym stimulovaním sa tieto inervačné vzory upevňujú a už nevyžadujú zapojenie mozgovej kôry. Vo futbale tieto motorické inervačné vzory predstavujú napr. vedenie lopty, technika kopu pri štandardných situáciách, obchádzanie súpera, prihrávanie na rozdielnu vzdialenost' a pod. Ak sú v priebehu tohto učenia prítomne aj emócie, čiže limbický systém, tak to vytvára priaznivé prostredie pre lepšie upevnenie si konkrétneho pohybu. Ak celý problém chápeme komplexnejšie, tak nie len na upevnenie konkrétneho pohybu, ale aj na upevnenie konkrétnej hernej situácie, resp. riešenia hernej situácie. V tréningovom procese by sme preto mali $\mathrm{v}$ čo najväčšom množstve vyberat' také tréningové prostriedky, ktoré by najčastejšie stimulovali herné situácie, ktoré sa vyskytujú v zápase, aby sme dosiahli u hráčov toho efektu, že budú senzitívnejšie reagovat' na zmenené podmienky v hre, či už zmenou postavenia lopty, súpera alebo vlastných spoluhráčov.

Podstatu jednotlivých zmien experimentálneho súboru môžeme tiež vidiet' v jednom z ukazovatel'ov a to $\mathrm{v}$ počte opakovaní. $\mathrm{V}$ tomto prípade platí, že ak sa zvýši objem tréningových hodín zložitejších metodických foriem, teda $\mathrm{v}$ našom prípade prípravných hier, zvýši sa aj počet opakovaní (herná situačnost').

\section{ZÁVERY}

Vzhl’adom k dosiahnutým výsledkom môžeme povedat', že nami vytvorený program experimentálnej skupiny pozitívne vplýva na nárast výkonnosti v motorických testoch, ale hlavne na herný výkon družstva. Zložitejšie prístupy $\mathrm{v}$ tréningovom procese, teda dominantné postavenie malých foriem prípravných hier. Jedná sa o prípravné hry s malým počtom hráčov, ktoré dosahujú maximálny počet 5 na 5 a nižšie $(1: 1,2: 2,3: 3,4: 4)$, kde využívame rôzne variácie početnosti hráčov, či už 
v prečíslení, alebo v podčíslení $(2: 1,3: 2,4: 2,5: 3$, atd'.). Domnievame sa, že negatívny výsledok koeficientu efektivity je zapríčinený hlavne nedostatkom malých foriem prípravných hier zameraných na častú strel'bu, respektíve zakončenie na bránku zodpovedajúcich rozmerov danej kategórie. Preto odporúčame využívat' $\mathrm{v}$ tréningovom procese malé formy prípravných hier s brankárom a na bránku, ktorá zodpovedá rozmerom brán vypovedajúcich z pravidiel danej kategórie. Na hráčov odporúčame pôsobit' multifaktoriálne, teda všetkými faktormi, ktoré determinujú herný výkon. Využitím teórie adekvátneho krytia, zápasových podmienok v tréningovom procese, neustále opakovanie a herná situačnost' zabezpečí trvalé automatizmy rýchleho riešenia herných situácií typických pre obrannú a útočnú fázu hry.

\section{Literatúra}

Bangsbo, J. (1994). The physiology of soccer with special reference to intense intermittent exercise. Acta Physiologica Scandinavica. [online] Február, 1994 [Citované 27.03.2014]. Dostupné z https://www.researchgate.net/publication/15138858_The_physiology_of_soccer-- with_special_reference_to_intense_intermittent_exercise.

Bisanz, G. (1983). Fussbaltraining im Kidnes - und Jugendalter. In Fussbaltrainig, č. 3. 33-36.

Bisanz, G. (1986). Das Training das 10- bis 14 jährigen Jungen und Mädchen. In Fussbaltraining, 5. 14-21.

Bisanz, G. (1989). Das Training das 14- bis 16 jährigen Jungen und Mädchen. In Fussbaltraning, 5. 25-32.

Brügemann, D. (1982). Kinder- und Jugendtraining. Fussball Handbuch Band 2.Schondorf: Hoffmann Verlag.

Buzek, M., \& Prochádzka, K. (1999). Česká futbalová škola. Praha: Olympia.

Carling, CH. (2001). Sports science support at the French Football Federation. In: Insight. The F.A. Coaches Association Journal. 4(4) London: The Football Association.

Fini, F. (1989). Beeinträchtig der Hochleistungsfussbal die Etwicklung der jungen Fussbalspieler? In: 3. Kurs der UEFA fur Junioren-National Trainer. Clairfontaine-en-Yvelines, 39-41.

Hedergott, K. H. (1973). Neue Fussball Lehre. Frankfurt am Mein: Wihelm - Limpert Verlag.

Hill-Haas, S., Coutts, A., Rowsel, G., \& Dawson, B. (2008). Variability of acute physiological responses and performance profiles of youth soccer players in small-sided games. Journal of Science and Medicine in Sport. [online] Júl 2007, 11(5) [Citované 27.03.2014] Dostupné z http://www.sciencedirect.com/science/article/pii/S1440244007001508\#.

Hill-Haas, S. V., Dawson, B. T., Coutts, A. J., \& Rowsell, G. J. (2009). Physiological responses and time-motion characteristics of various small-sided soccer games in youth players. Journal of Sports Sciences. [online] August 2010, 27(1) [Citované 27.03.2014] Dostupné z http://www.ncbi.nlm.nih.gov/pubmed/19834345.

Hoff, J., Wisloff, U., Engen, L. C., Kemi, O. J., \& Helgerud, J. (2002). Soccer specific aerobic endurance training. British Journal of Sports Medicine. [online] Jún 2002, 36(3) [Citované 27.03.2014] dostupné http://www.ncbi.nlm.nih.gov/pub$\mathrm{med} / 12055120$.

Jones, S., \& Drust, B. (2007). Physiological and technical demands of 4 v 4 and 8 v 8 games in elite youth soccerplayers. Kinesiology, [online] Január, 2007. 39(2) [Citované 27.03.2014]. Dostupné $z$ http://www.google.sk/url?sa=t\&rct=j\&q=\&esrc $=s \&$ source $=$ web\& $c d=1 \&$ ved $=0 C C c Q F j A A \& u r l=h t t p \% 3 A \% 2 F \% 2 F h r c a k . s r c e . h r \% 2 F f i l e \% 2 F 34544 \&$ ei=WM8zU9D8G8HxhQfo- IH4Dw\&usg=AFQjCNEdPusxYEpc2foiuqEIF4S91vb_rg\&bvm=bv.63808443,d.bGE.

Israel, S., \& Eissmann, H. J. (2007). Children and young people in football. In: Medicine matters, č. 15. Nyon: UEFA's Footbal development divisions, s. 8-11.

Kačáni, L. (2000). Futbal. Teória a prax hernej prípravy. Bratislava: SPN.

Kačáni, L. (1980). Model technicko-taktickej prípravy futbalistov. Metodický list č. 46. Bratislava: Šport.

Kačáni, L., \& Horský, L. (1988). Tréning vo futbale. Bratislava: Šport.

Lochmann, M. (2001). Leistungsrelevante Merkmale im Fussball und ihre Bedeutung fur die Trainingssteuerung. In Leistungsdiagnostik und Coaching im Fussball. Betreige und Analysen zum Fussballsport XIII. Hamburg: Czwalina.

Maclaren, D., Davis, K., Isokova, M., Mellor, S., \& Reilly, T. (1988). Physiological strain in-a-side soccer. In T. Reilly, A. Lees, K. Davis, W.J. Murphy (Eds.), Science and Football.

Mallo, J., \& Navarro, E. (2008). Physical load imposed on soccer players during small-sided training games. The Journal of Sports Medicine and Physical Fitness. [online] October 2008, Volume 48(2) [Citované 27.03.2014]. Dostupné z http:// europepmc.org/abstract/MED/18427410.

McMorris, T. (1999). Excercise, plasma, catecholamine concetrations and decision-making performance of soccer players on a sport-specific test. In Journal sport science. New York: Routlege. 17(8). 667-676.

Peráček, P. (2014). Talent vo futbale I. Bratislava: Fakulta telesnej výchovy a športu UK.

Peráček, P. (2012). Kvalita útočnej fázy hry. In Telesná výchova a šport, 4. 2-7.

Peráček, P. (2004). Príprava reprezentačných družstiev mládeže vo futbale. 1. vyd. Bratislava: Slovenský futbalový zväz.

Peráček, P. (2003). Športové hry. Bratislava: Peter Mačura PEEM. 
Peráček, P. (2001). Futbal. Riadenie - plánovanie - tréning. 3. vyd. Bratislava: Peter Mačura - PEEM.

Peráček, P. (1993). Teória a didaktika zvoleného športu futbal. Vysokoškolské skriptá. Bratislava: FTVŠ UK.

Peráček, P. (1992). Efektívnost' športovej prípravy mladých futbalistov. Kandidátska dizertačná práca. Bratislava: FTVŠ UK.

Perič, T. (2004). Sportovní príprava dětí. Praha: Grada Publishing.

Rampini, E., Impellizzeri, F. M., Castagna, C. G., Chamari, K., Sassi, A., \& Marcora, S. M. (2007). Factors influencing physiological responses to small-sided soccer games. Journal of Sports Sciences. [online] Apríl 2007, 25(6) [Citované 27.03.2014] Dostupné z http://www.ncbi.nlm.nih.gov/pubmed/17454533.

Reilly, T., \& White, C. (2004). Small-sided games as an alternative to interval-training for soccer players. In T. Reilly, J. Cabri, \&D. Araújo, Science and Football V. London and New York: Routledge Taylor \& Francis Group.

Štulajter, V., \& Peráček, P. (2004). Fyziologické aspekty motorického učenia a regulácie pohybov a vybrané aspekty humánnej etológie športu vo futbale. In Zborník vedeckých prác Katedry hier FTVŠ UK, 2.

Vengloš, J. (1988). Poznatky z mládežníckeho futbalu vo svete. In Skvalitnenie športovej prípravy mladých futbalistov. Metodické listy č. 6. Bratislava: VFZ SúV ČSZTV.

Ward, P. (2002). What Are the Ingredients For Success? Practice, Play, Match Play, Specialisation and Sporting Diversity. In: Insight. The F.A. Coaches Association Journal. 3(5). 28-30.

Weineck, J. (2000). Optimales Training. Leistungpchysiologische Trainingslehre unter besonderer Berucksichtigung des Kindern und Jugendtrainings. Balingen: Spitta - Verl.

Williams, A. M. (2003). Training perceptual skill in field hockey: is there transfer from laboratory to the field?. In Research quarterly for exercise and sport Liverpool. AAHPERD, 74(1). 98-103.

Žamba, M., \& Holienka, M. (2012). Praktické ukážky tréningových jednotiek futbalistov zameraných na rozvoj vybraných koordinačných schopností špecifickými prostriedkami. In Telesná výchova a šport. 3. 30-33. 